\title{
Management of Seaport Real Estate Stock in Relation: Port - Marine City
}

\begin{abstract}
The issue of managing real estate seaport stock is multidimensional. The issue requires taking into account not only the location and economic factors but also the aesthetic. The aesthetic factor is closely linked to the behavior of spatial order in the port-city. The key task in this area is satisfied by the manager's seaports. In this paper, the authors analyzed the real estate seaport stock management system in Port of Gdansk (Poland). The system operates under different laws; in particular, the Act of 20 December 1996 on Ports and Harbors [2] and other.

The aim of this article is to identify some activities of the Port of Gdansk Authority SA in the context of the Act on Ports and Harbors as they relate to the functionality of the management of the port real estate in the city of Gdansk as well as to identify factors that affect the current management of port real estate. Results of the analysis showed the procedures of the current and prospective resource management and the need to create a real estate stock management system. The authors pointed out the directions of sustainable management of the seaport real estate stock on the basis of the focus research.

An innovative approach to this issue is to indicate the method of collecting data for the management of a specific resource that is a resource of port real estate. Port of Gdansk is a corporation that combines the duties of space management and conducts activities related to maritime transport.
\end{abstract}

Keywords: real estate management, real estate stock of seaports, port-city, Port of Gdansk Authority SA

\footnotetext{
* University of Warmia and Mazury in Olsztyn, Department of Real Estate Resources, Olsztyn, Poland

** Port of Gdansk Authority SA, Gdansk, Poland
} 


\section{Introduction}

Seaports are located at the interface between land and sea, separated by administrative boundaries, spatially extensive transport and manufacturing complexes, suitable technical and organizational terms to facilitate the movement of cargo and passengers in the relationship of land and sea [7]. The definition of a seaport indicates its essential aspect of which is the spatial location - the location, extent, and separation from adjacent areas with different properties [7].

Market developments have created the need for ports to be a part of wider logistics networks and to provide value-added services using the port infrastructure and its resources [10]. After Mahfouz and Arisha [13], seaports are required to evolve from traditional port functions (i.e., loading and discharging) to more-advanced activities that could add complexity to the management of internal port operations and its stock. Port investment is an important issue facing port management. Arising from the complex nature of ports, analyzing investments in ports includes investment in port real estate, infrastructure, superstructure, and hinterland connection [10, 14].

Owing to the fact that most port systems are still administrated by public authorities, many issues are needed to investigate scenarios that create opportunities for further research. Various authors suggested that one of the most critical elements influencing seaport performance is the port reformation process and the overlap between public and private ownership $[6,8,9,11,12,18]$.

As manager of the seaport, Port of Gdansk Authority SA is a public company. It carries out the tasks it is delegated to perform under the different laws; in particular, the Act on Ports and Harbors. This act considers property management as an important field of activity of the managing body. This task requires an extensive system of recording ownership of the real estate, the current resource management, and procedures to acquire and dispose of real estate.

The purpose of this article is to identify some activities of Port of Gdansk Authority SA in the context of the Act on Ports and Harbors as they relate to the functionality of port real estate in the city of Gdansk as well as to identify the internal and external factors that affect the current management of port real estate.

\section{Material and Methods}

In this paper, qualitative research based on a focus analysis of seaport real estate stock management as it relates to the port and marine city was conducted as a case study. The method of managing such specific real estate stock has been long-established by the legislation of a particular organizational system. It is a multidimensional process that should take into account spatial, economic, social, and environmental aspects. One of the major problems is the real estate management's respect for the needs of the port-marine city. 
The object of the research is the process of seaport real estate stock management. The study includes a number of key issues outlined in the diagram (Fig. 1).

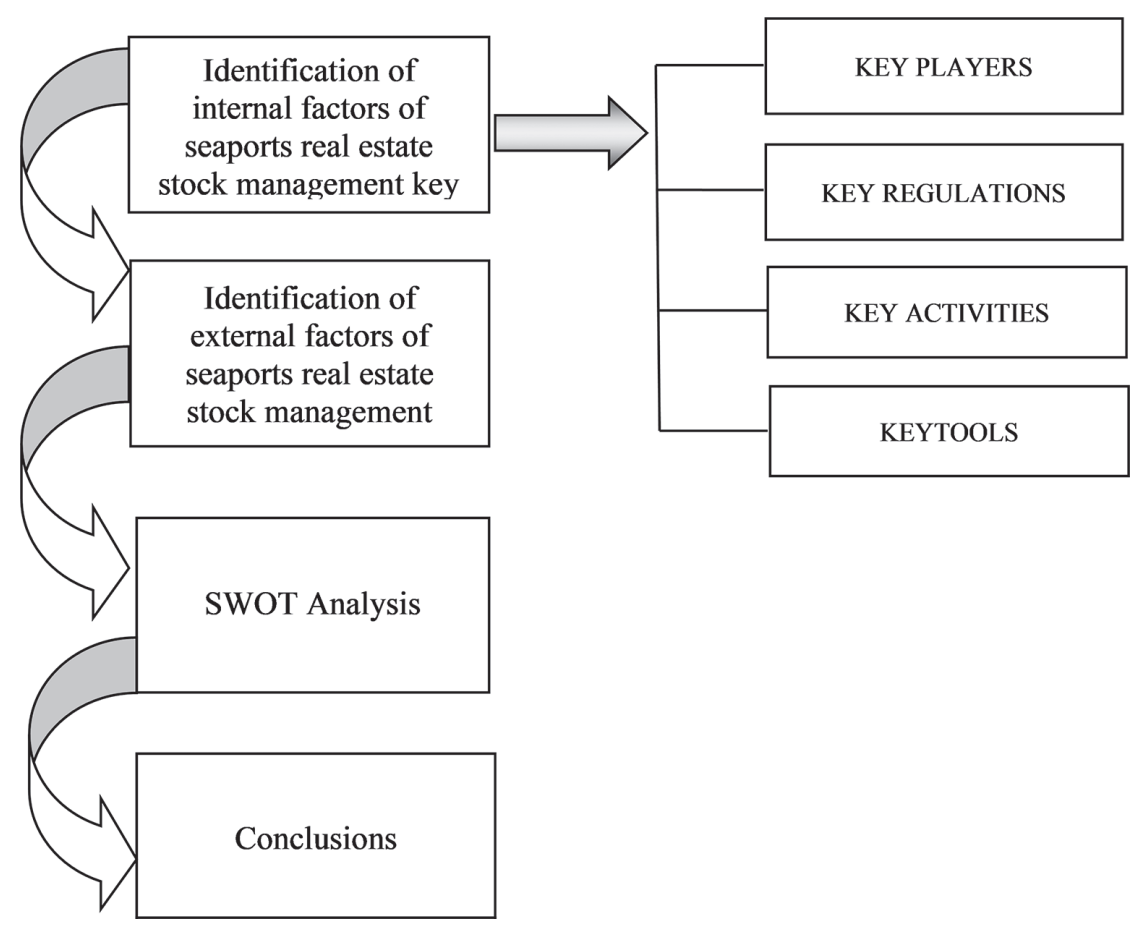

Fig. 1. Study organization diagram. Source: elaborated by the authors

The complete and in-depth analysis of a specific real estate management system enables us to separate the trends of sustainable management.

\section{Results and Discussion}

\subsection{Identification of Internal Factors of Seaport Real Estate Stock Management}

Regulation of the Minister of Transport, Construction, and Maritime Economy of 29 May 2012 on determining the border seaport of Gdansk from the sea, roadstead, or land determines the area of the seaport of Gdansk [16]. It is worth pointing out that the area of the port of Gdansk is not uniform. Regulation establishes the enclave, which also includes the residential areas. The legal regime provided for port areas exclude the Stogi and Krakowiec - Górki Zachodnie urban districts, the Przeróbka urban district, and areas of the Szczecińskie Waterfront (Figs. 2-4). 


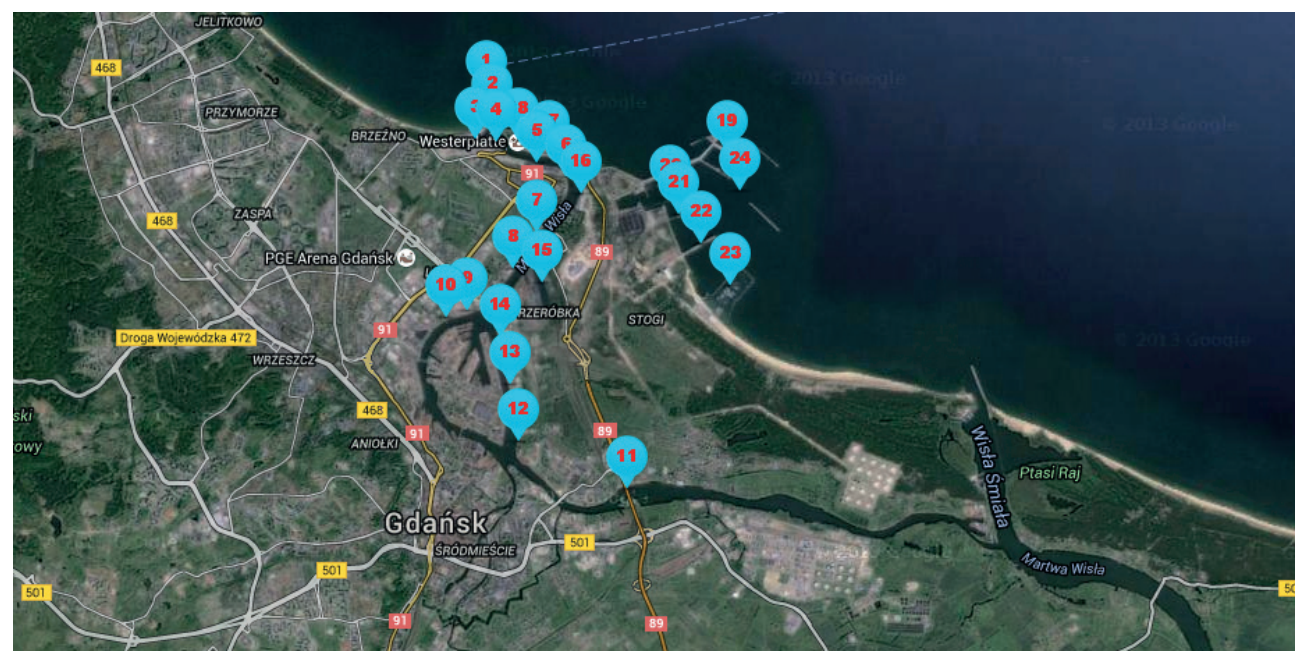

Fig. 2. Location of real estate stock of Gdansk seaport. Designation: 1 - The entrance to the inner port; 2 - Port channel; 3 - Free zone; 4 - Captain Ziółkowski Waterfront; 5 - Oliwskie Waterfront; 6 - Turn Five Whistles; 7 - Zbożowe Waterfront; 8 - Wiślane Waterfront; 9 - Szczecinskie Waterfront; 10 - CPN4 Waterfront; 11 - suspended bridge by the Dead Vistula; 12 - Bytowskie Waterfront; 13 - Industrial Waterfront; 14 - Chemists Waterfront; 15 - Mining Swimming Pool; 16 - Defenders of the Polish Post Waterfront; 17 - Westerplatte Ferry Terminal; 18 - Defenders of Westerplatte Waterfront; 19 - Base Liquid Fuels; 20 - Coal Terminal; 21 - Terminal LPG; 22 - Pirs Rudowy; 23 - Container Terminal DCT Gdansk; 24 - The external port

Source: [25]

The area of land within the administrative boundaries of the Gdansk port is 652 ha land and 412.56 ha of surface waters [21]. The main areas of port activity are the internal port - cargo handling area (mostly the eastern part of the inner port), mass handling area (mainly the western part of the inner harbor), and external port [15]. The external port is associated with the activities of deep-water terminals.

Management of the seaport of Gdansk is entrusted to Port of Gdansk Authority SA (PGA SA). Port of Gdansk Authority SA is a joint stock company. The law on ports and harbors regulate the fundamental principles of the functioning of port management entities. Among the subjects of activity of those companies are, inter alia, property management and the acquisition of port infrastructure and real estate for the purpose of port development. PGA SA takes action in both areas. First of all, it offers the real estate for lease. More than $50 \%$ of the real estate in perpetual usufruct of the PGA SA is leased. The other grounds are prepared to be taken over by counterparties. PGA SA dispose of investment land with an area of more than 14 hectares, which can immediately become the subject of lease [22]. PGA SA also announces tenders for the lease of property if the property has the specific 
properties (e.g., lease of developed real estate, including Pirs Rudowy destined for the construction and operation of a widely available deepwater terminal, including transhipment of goods of plant origin, with the exception of crude oil and petroleum products, located in the Port of Gdansk in the Outer [23]).
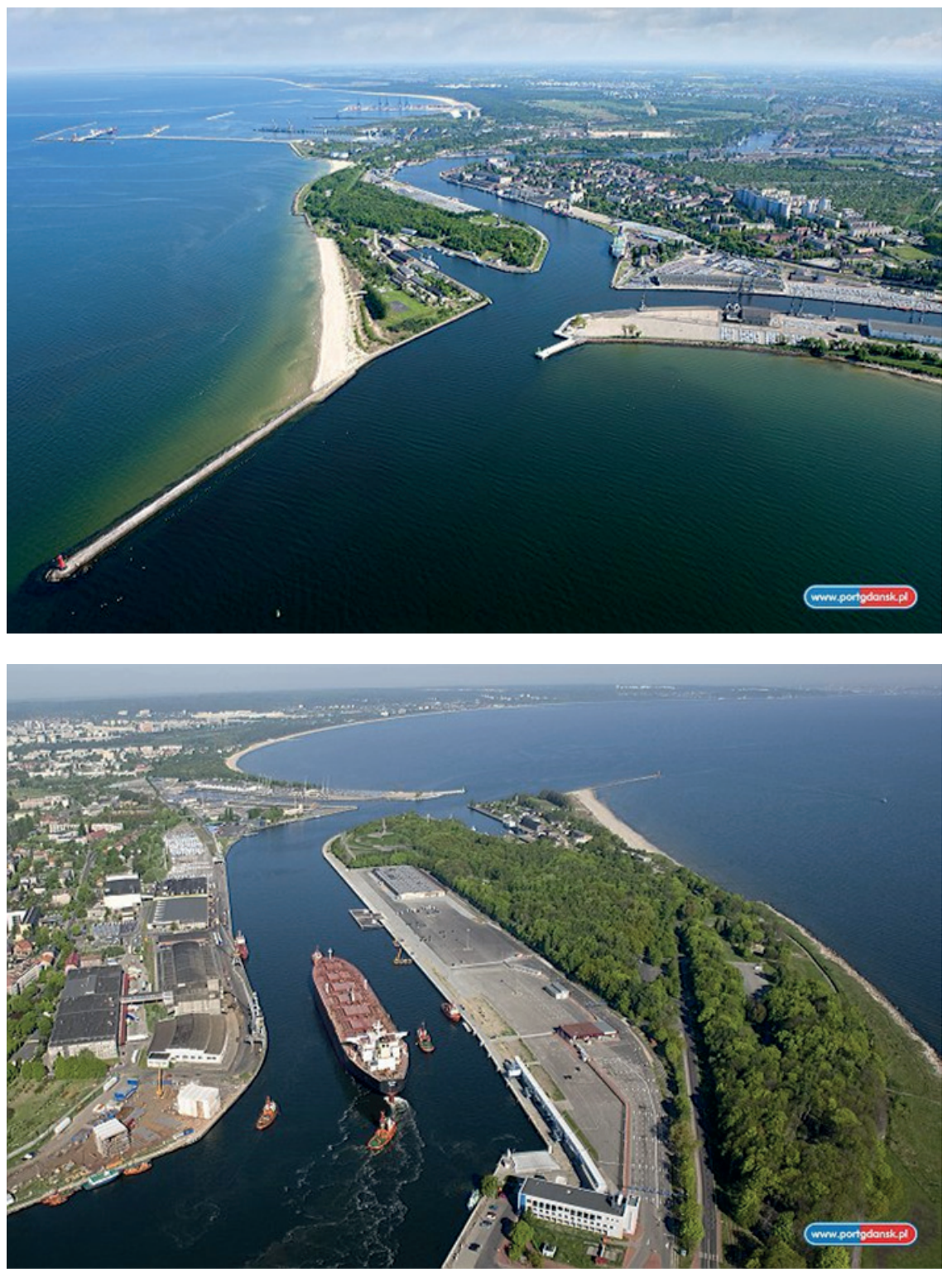

Fig 3. View of entrance to port

Source: [24] 


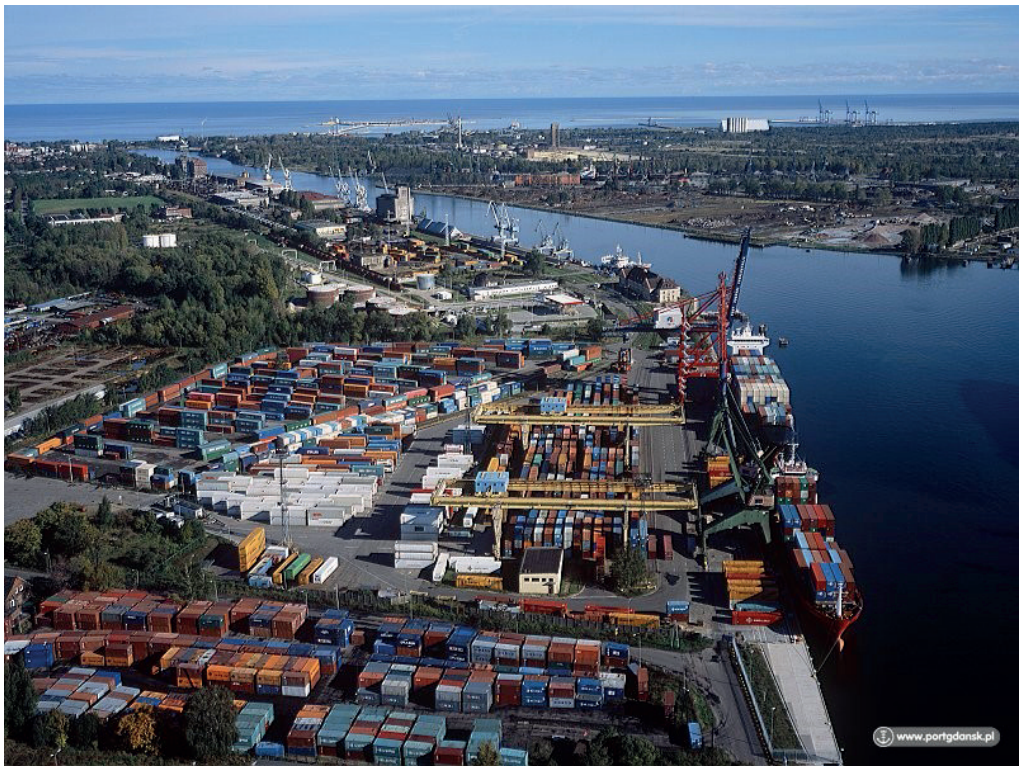

Fig 4. View of Szczecińskie Waterfront - Container Terminal

Source: [24]

Table 1 summarizes the basic information about the entity, legal regulation range, and mode of action in the process of the real estate stock of seaport management.

Table 1. General information about Port of Gdansk

\begin{tabular}{|c|c|}
\hline Key issue & Port of Gdansk \\
\hline Responsible entity & Port of Gdansk Authority SA \\
\hline $\begin{array}{l}\text { The management entity } \\
\text { (a separate section) }\end{array}$ & $\begin{array}{l}\text { Land Register and Environmental Protection Department } \\
\text { (including Land Registry team and Spatial Information Team) }\end{array}$ \\
\hline The rules in force & - Act on Ports and Harbors [2] \\
\hline $\begin{array}{l}\text { Surface area by type of } \\
\text { real estate in hectares }\end{array}$ & $\begin{array}{l}\text { - } 667 \text { hectares of land in perpetual usufruct, including real estate built and } \\
\text { unbuilt [Annual Report } 2014 \text { of Port of Gdansk Authority SA], } \\
\text { - the lack of land held in property }\end{array}$ \\
\hline $\begin{array}{l}\text { The range of } \\
\text { management } \\
\text { (acquisition, disposal, } \\
\text { etc.) }\end{array}$ & $\begin{array}{l}\text { - acquisition of real estate through civil law transactions, } \\
\text { - acquiring right of perpetual usufruct of land through contracts with the } \\
\text { State Treasury or Municipality, } \\
\text { - selling real estate through civil law transactions, } \\
\text { - dissolving the perpetual usufruct right }\end{array}$ \\
\hline $\begin{array}{l}\text { Purpose of the } \\
\text { acquisition of property }\end{array}$ & $\begin{array}{l}\text { - management entity performs property management and acquisition for } \\
\text { the development of the port, } \\
\text { - the use of land for the construction of port infrastructure devices } \\
\text { (e.g., waterfront, road network infrastructure), } \\
\text { - real estate transfer (based on lease agreements) for the contractors for use } \\
\text { (to do business/transhipment) }\end{array}$ \\
\hline
\end{tabular}

Source: Annual Report 2014 of Port of Gdansk Authority SA 


\subsection{Acquisition of Real Estate to Seaport Stock}

Acquisition of real estate by the operator of a seaport can be analyzed in the context of three basic laws: Civil Code [1], the Real Estate Management Act [2], and the Act on Ports and Harbors. The Civil Code formulates the general conditions to be met by those entities engaged in legal activities in the field of real estate. Port of Gdansk Authority SA occurs at the level of civil law as both the seller and buyer. Over the last five years, PGA SA has made one acquisition the right of perpetual usufruct from capital company in this period of time PGA SA sold the rights of perpetual usufruct of land together with the ownership of equipment that is situated on the land. PGA SA entered into one agreement to establish the right of free perpetual usufruct of land with an area of 286,227 $\mathrm{m}^{2}$, pursuant to art. 4 a of the Act on Ports and Harbors. Current procedures for acquisition are conducted in the following modes: establishment of rights to use of the property of the Treasury in the no-tender procedure $\left(17,697 \mathrm{~m}^{2}\right)$, establishment of rights to use of the property of the City of Gdansk in the no-tender procedure $\left(3824 \mathrm{~m}^{2}\right)$, free establishment of perpetual usufruct of the Treasury $\left(14,918 \mathrm{~m}^{2}\right)$, acquisition through exchange of property of the City of Gdansk $\left(19,175 \mathrm{~m}^{2}\right)$, and disposal by exchange to the Municipality of Gdansk right of perpetual usufruct of PGA SA (15,487 m²) [Annual Report 2014 of Port of Gdansk Authority SA].

The procedure for the acquisition of property starts with a request to the Board of PGA SA for a resolution approving the initiation of the procedure for obtaining the rights to a property. The initiator of the process is primarily a commercial division, which operates under the Department of Cooperation (along with its counterparties). This unit has direct contact with potential tenants of the port areas and also receives information from entities operating in the port about the areas that are attractive from their point of view. The necessity of acquiring the rights to real estate is also reported by special units of the Technical Department. In carrying out their tasks, this unit states the need for land acquisition. The procedure for the acquisition of property in accordance with Article 4a of the Act on Ports and Harbors initiated essentially as another step associated with an investment by the contractor's port.

The regime of the Real Estate Management Act is important in connection with the fact that PGA SA has only a right of perpetual usufruct. In this case, the procedure the acquisition of law to the land is a procedure without an auction. Article 4 of the Act on Ports and Harbors grants the managing body power in the form of the right of pre-emption and priority. The provision emphasizes the position of seaport management company as the company being privileged in real estate trading that is located in the administrative boundaries of the port.

The proposal for establishing a perpetual usufruct right in the mode without auction or free of charge (Art. $4 \mathrm{a}$ of the Act on Ports and Harbors) PGA SA presents to the Mayor of Gdansk. A statute of the PGA SA limits the amounts in the procedure for acquiring the rights to the property. When the value of a particular law 
will be higher than 50,000 euros, it is necessary to obtain approval of the General Meeting of Shareholders of the company for this transaction. The application for passing a resolution by the General Meeting must be accompanied by a resolution of the Supervisory Board, giving its opinion on its intention to acquire the rights to the property. It must be with the consent of the Minister of State Treasury for conclusion of the contract to obtain the rights to the property. Consent is required to donate the property use or collect benefits for more than ten years. The minister can refuse to give his/her consent when this may cause a threat to state security or defense or because of other important public interests (based on the Act on Ports and Harbors).

The Act on Ports and Harbors enacts the right of first refusal in favor of the managing body or the Treasury. The port management entity has first refusal in the case of sales of real estate; this task goes to the Treasury if port management does not exercise its right of pre-emption. First refusal in the case of perpetual usufruct is only entitled to the managing body. Disposal of real estate without the implementation of first refusal is invalid.

\subsection{Seaport Real Estate Stock Management - Supported Tools}

Real estate management by Port of Gdansk SA requires keeping records of the land within the administrative boundaries of the port. The function of record of real estate fulfill the two tools: Microsoft Access and GIS software. The first of these tools gathers information about all cadastral parcels within the seaport of Gdansk. This database includes general information about the property, such as its size, its number in the land register, its address, its owner and eventual perpetual usufructuary user, the nature of the land, and its coverage by a particular local spatial development plan. The database contains fields where comments or information on the notification of first refusal can be entered. Each registered parcel of land is classified into categories: in the administrative boundaries of the port, some within or outside the port. Entering information into the database of real estate located outside the Port of Gdansk is mainly connected with the fact that the administrative boundaries are not rigid. The regulation currently in force in this matter replaced an earlier regulation of the Minister of Transport and Maritime Economy of 23 November 1998 on the establishment of the border from the land-side sea port in Gdansk [17]. The method of describing the boundaries of the port and the introduction enclaves makes the determination of whether the parcel is within the port can be very difficult. Microsoft Access allows us to search for a specific parcel number and determine whether it is located within the port (for example, in response to a question from a notary preparing the sale of a real estate transaction). The database is conducted to gather information on land parcels held in the administrative boundaries of the port. Another tool to assist property management is GIS software (e.g., the MapInfo program). The database (program) includes information presented in a graphical and descriptive way about the cadastral parcels of PGA SA and other entities as well 
as the technical infrastructure of the utility network. This program also collects information on PGA SA such as the area under lease by individual counterparties, the numbers and names of the fixed assets (quays, for example), the select areas where individual investment, and what development actions are planned.

A registry in the form of an Excel document is conducted for the property in perpetual usufruct by PGA SA. After changing, a new sheet is added that shows the condition of the property for a specific day. Records contains a lot of information about real estate: the land registration number, number of precincts, area, land and mortgage register number, unit value, fee for perpetual usufruct, address, nature of the soil, date and number of decision/agreement establishing a right of perpetual usufruct, number before the division parcel number (in the case of real estate created from the division or merge other parcels) according to the numbering before the change, and the date of the most-recent extract and draw from the register (which is collected by the Land Registry team).

\subsection{External Factors of Seaport Real Estate Stock Management}

Management of the port area is one of the basic tasks of the managing entity of the seaport. The implementation of this obligation is difficult because of the fragmentation of harbor land ownership. The Act on Ports and Harbors guarantees the right of first refusal in the administrative boundaries of the port for a management entities of ports and the State Treasury. This institution was intended to allow the progressive redemption of port areas by authorized entities and prevented their purchase by businesses not related to the maritime or port. The 'strategy of developing sea ports by 2015' envisaged the creation of a special reserve in the budget of the Ministry of Maritime Economy of Poland for the purpose of acquiring port real estate. This objective has not been achieved. Port management entities and the State Treasury seldom exercise their right of first refusal, mainly because of their limited financial resources [15]. The Port of Gdansk has not bought any real estate over the last five years in this mode. Pluciński indicates that the dominant strategy was developing port space expansion into new areas of the external port. The realization of this strategy was, among others, the purchase of land for a container terminal [15].

Grzelakowski and Matczak point out that a necessary aspect of the analysis in the management of the port area is the concept of spatial order. Market indications as key elements in location decisions may lead to spatial conflicts in the long-term. Port development should be sustainable and take into account the spatial, economic, social, and environmental aspects. A spatial order shaping consists of working out long-term strategies for land port areas, coordinating their compliance with local land development plans, and plans for changes on how to use the port land [7]. PGA SA takes action in all three of the areas listed above. The development strategy of the Port of Gdansk identifies areas that may pose as an expansion area of port 
functions. This document is also used in the analysis of real estate transactions in respect to which port management entity has the right of first refusal. The company's organizational regulations includes the departments substantive responsibilities of monitoring of changes in local land use plans in the administrative boundaries of the port and active cooperation in shaping their contents. An example of influencing the destiny of port areas can be tenders for the lease of land associated with running specific port activities. Focused actions for the development of port infrastructure also predisposes areas for a particular use.

PGA SA carries out the procedures aimed at obtaining rights to attractive land from the point of view of development of the sea port in Gdansk.

Szwankowski indicated the pervasive importance of the relationship port and marine city in the development of seaports. Infrastructural facilities and attractiveness for tourists are essential requirements of the localization of port business [19]. Links between the port and the city are important. Many areas within the administrative boundaries of the port are owned by the municipality, so they can be subject to the perpetual usufruct of the managing body. Now, PGA SA takes actions that seek to obtain the rights to municipal real estate with an area of 120,980 square meters [Annual Report 2014 of Port of Gdansk Authority SA]. The Mayor of Gdansk has agreed to transfer the municipal's property of real estate in a settlement of compensation for PGA SA real estate expropriated at the Sucharskiego route.

The following analysis have for the subject only the PGA SA property. A functional-spatial approach to the seaport suggests that the concept of ports and port real estate can be analyzed in a different perspective. This concept can be analyzed from the narrowest approach of the seaport as an area ruled by the managing body to the widest, which covers an area of a national and international port [15].

The real estate of PGA SA management is important because the property lies within the city limits. The property must not only meet the demands for the port but also interact with the city. It is important that the property looks aesthetically and is well tended.

\subsection{Strategic SWOT Analysis (Strengths and Weaknesses of Management, Opportunities and Threats)}

An analysis of the internal and external features of the seaport real estate management system and the author's experience working at Port of Gdansk Authority SA has led to the identification of the strengths and weaknesses of management, opportunities, and threats. For the purpose of a full understanding of the specificity of the seaport real estate resource management process, one of the most-popular heuristic analysis techniques (SWOT analysis, SWOT) is used to organize information. In this case, it was used to analyze the internal and external environment of specific real estate management. 
The SWOT analytical technique involves the segregation of case information into four groups (four categories of strategic factors):

- S (Strengths) - everything that is an asset or advantage; the advantages of the analyzed object,

- W (Weaknesses) - everything that is a weakness or barrier; defects of the analyzed object,

- $\mathbf{O}$ (Opportunities) - everything that provides the chance of positive change for an analyzed object,

- T (Threats) - everything that creates the risk of unfavorable changes for an analyzed object.

As a result of the interview inside the organization, the following features of the port real estate management system are distinguished:

\section{Strengths of management}

1. Land registration within the port administrative boundaries is (in the form of an Excel document) available to all employees of the Department on a common network location.

2. Full information on the property within the seaport of Gdansk.

3. Combination of graphic data with quality data in the GIS system.

4. Spatial and descriptive data stored in digital technology (data input from paper documents).

5. Staff constantly increases competence (system of training and education financing).

\section{Weaknesses of management}

1. Lack of integration of data from different subsystems (it is needed to make changes to the data in each subsystem).

2. Lack of full computerization of data about resource (most of the documents stored in paper form).

3. Manual processing of documents to the database.

4. Incomplete and outdated data sets related to land and property not owned by PGA SA.

5. No widely available data regarding the assets assigned to a specific cadastral plot.

\section{Opportunities of management}

1. Functional integration of data from records of land, GIS, and external information sources.

2. The introduction of integrated software for the visualization of spatial data, descriptive and official documents relating to resource.

3. Automation of archiving data on the land.

4. Expanding the collection of data on port infrastructure and other data that allow to estimate the amount of the fees associated with the property.

5. Incorporating the public sector to create a system providing data by public entities of real estate located and the administrative boundaries of the port. 


\section{Threats of management}

1. Limited ways of obtaining data on the land in the administrative boundaries of the port.

2. Too-high prices for data obtained from the land register.

3. No permanent cooperation with units gathering specific data for its own operations.

4. The slow pace of disclosure related to public land registries.

5. Lack of uniform and clear rules defined for individual data in the public registers.

The conducted SWOT analysis allowed us to identify what needs to be improved for property management to be more effective. Identifying the strengths and weaknesses pointed out weaknesses in the management of port property, thus allowing the managing entity to be able to improve its functioning. The analysis was carried out jointly with an employee of the Port of Gdansk. Access to the selected data about port real estate for all port administration personnel allows for harmonious management from the various port sub-units. As an example, people responsible for renting buildings or storing products transported by sea can follow the steps of repair work performed by people from other sub-units or logistic plans of product relocation by people from the logistics administration. Unfortunately, the lack of all data in a digital form slows down the actions. This sometimes can lead to conflicts in the management responsible for various tasks.

The identified weaknesses reveal the need to build a comprehensive industry system that includes all information about the real estate, stocks, and digital products. A lack of complete data makes it difficult to optimize the port and resource management at all levels of the port administration. The current design of the system (composed of subsystems) is a cause of difficulty in the building of one network. Updating the associated data often requires the duplication of work in each of the subsystems where the data should be input once and automatically referenced to other subsystems through reference objects. The manual processing of paper documents into the database generates typographical errors that can lead to discrepancies and enforce the verification of source documentation. Such actions slow down the decision-making processes or may lead to erroneous decisions. Therefore, additional monitoring functionality that excludes erroneous entries in a data-update program and the introduction of one active system without the need for the continuous integration of subsystems should be introduced. An industry-specific system integrated with the national Land Administration System as well as the use of GIS tools for spatial analysis will provide an excellent basis for the efficient management of seaports. LAS will provide data not only on port property but also on city property; consequently, it will improve management at the touch of managerial qualities. Then, the transition area will be optimally used.

LAS integrated with the port information system can help eliminate conflicts in the port - marine city relationships. 


\section{Conclusions}

Port of Gdansk Authority SA as manager of seaport property carries out the tasks delegated to perform under the laws (in particular, the Act on Ports and Harbors). This act considers property management as an important field of activity of the managing body. This task requires an extensive system recording all data on real estate and current resources for management and conduct procedures to acquire and dispose of real estate. Port of Gdansk Authority SA takes action in this regard on the basis of separate organizational units.

The availability of full information on the resource of the organization, internal and external factors, and functioning of ports in the port cities will provide the basis for sustainable land-water management, as described in detail.

The chances are in licensing access to the National Land Administration System (LAS) called the Integrated Real Estate Information System (IREIS). IREIS will be a multi-purpose system available for public authorities and individuals. It will functionally integrate the Real Estate Cadastre, Land Register, Register of Economic Entities (REGON), Population Register (PESEL), land-use plans, national register of the territorial administration division (TERYT), and many other public registers that contain current data on real estate. Unfortunately, work is still ongoing related to the harmonization of data, and IREIS has not been fully functional. However, it is important that the currently opening industry databases of port infrastructure and movables are harmonized with the spatial databases of SDI (Spatial Data Infrastructures) in national data standards. This enables enough good management of the port real estate.

LAS and the industry databases of port infrastructure and movables need integration, which is necessary to make the right decisions at the crossroads of managing cities and ports. The Polish government's activity in the direction of lunching the Integrated Real Estate Information System is appropriate and justified towards the accomplishment of a number of public real estate registers [5]. Integrating the industry system with the national Land Administration System and using GIS tools for spatial analysis would provide an excellent basis for the efficient management of the seaport and adjacent area that is under the management competence of the city administration.

\section{References}

[1] Act of 23 April 1964 Civil Code. Journal of Laws 2017, item 459 [Ustawa z dnia 23 kwietnia 1964r. Kodeks cywilny. Dz.U. 2017, poz. 459].

[2] Act of 20 December 1996 on Ports and Harbors. Journal of Laws of 2010. No. 33, item 179 [Ustawa z dnia 20 grudnia 1996 r. o portach i przystaniach morskich. Dz.U. 2010, nr 33, poz. 179]. 
[3] Act of 21 August 1997 on Real Estate Management. Journal of Laws of 2016, item 2147 [Ustawa z dnia 21 kwietnia 1997 r. o gospodarce nieruchomościami. Dz.U. 2016, poz. 2147].

[4] Daamen T.A., Vries I.: Governing the European port-city interface: institutional impacts on spatial projects between city and port. Journal of Transport Geography - Institutions and the Transformation of Transport Nodes, vol. 27, 2013, pp. 4-13.

[5] Dawidowicz A., Klimach A., Szpara A.: Gospodarowanie mieniem portowym $i$ mieniem gminnym - zarys problemu [Management of real estate seaports and municipal resources - comparative approach]. Acta Scientarum Polonorum Administratio Locorum, 14(3), 2015, pp. 21-42.

[6] Everett S.: Port reform in Australia; regulation constraints on efficiency. Maritime Policy \& Management, vol. 34, no. 2, 2007, pp. 107-119.

[7] Grzelakowski A.S., Matczak M.: Wspótczesne porty morskie. Funkcjonowanie i rozwój [Modern seaports. Functioning and development]. Akademia Morska, Gdynia 2012.

[8] Hoyle B.S.: The port-City interface: Trends, problems and examples. Geoforum, vol. 20, issue 4, 1989, pp. 429-435.

[9] Hall P.V., Jacobs W.: Why are maritime ports (still) urban, and why should policy-makers care? Maritime Policy \& Management, vol. 39, no. 2, 2012, pp. 189-206.

[10] Hilda M., Meersman A.: Port investment in an uncertain environment. Research in Transportation Economics, vol. 13, 2005, pp. 279-298.

[11] Hoyle B.S.: Global and local change on the port-city waterfront. Geographical Review, vol. 90, issue 3, July 2000, pp. 395-417.

[12] Jacobs W., Ducruet C., De Langen P.: Integrating world cities into production networks: the case of port cities. Global Networks, vol. 10, 2010, pp. 92-113, doi: 10.1111/j.1471-0374.2010.00276.x.

[13] Mahrouz A., Arisha A.: Seaport management aspects and perspectives: an overview [paper presented at the $12^{\text {th }}$ Annual Irish Academy of Management Conference, At Galway, Ireland]. Galway-Mayo Institute of Technology, Galway, Ireland 2009.

[14] Paixao Casaca A.C.: Simulation and Lean port Environment. Maritime Economics \& Logistics, vol. 7, 2005, pp. 262-280.

[15] Pluciński M.: Polskie porty morskie w zmieniajacym się otoczeniu zewnętrznym [Polish sea ports in a changing external environment]. CeDeWu, Warszawa 2013.

[16] Regulation of the Minister of Transport, Construction and Maritime Economy of 29 May 2012 on determining the border sea port of Gdansk from the sea, roadstead or land. Journal of Laws of 2012, item 650 [Rozporzadzenie Ministra Transportu, Budownictwa i Gospodarki Morskiej z dnia 29 maja 2012 r. w sprawie ustalenia granicy portu morskiego w Gdańsku od strony morza, redy i ladu. Dz.U. 2012, poz. 650]. 
[17] Regulation of the Minister of Transport, Maritime Economy of 23 November 1998 on determining the border sea port from land in Gdansk. Journal of Laws of 1998, No. 146, item 960 - archival [Rozporzadzenie Ministra Transportu i Gospodarki Morskiej z dnia 23 listopada 1998 r. w sprawie ustalenia granicy od strony ladu portu morskiego w Gdańsku. Dz.U. 1998, nr 146, poz. 960].

[18] Robinson R.: Regulating efficiency into port-oriented chain systems: export coal through the Dalrymple Bay terminal, Australia. Maritime Policy \& Management, vol. 34, no. 2, 2007, pp. 89-106.

[19] Szwankowski S.: Funkcjonowanie i rozwój portów morskich [The functioning and development of seaports]. Wydawnictwo Uniwersytetu Gdańskiego, Gdańsk 2000.

[20] Verhoeven P.: A review of port authority functions: towards a renaissance? Maritime Policy \& Management, vol. 37, no. 3, 2010, pp. 247-270.

[21] LINK 1: Website of the Port of Gdansk Authority SA: http://www.portgdansk.pl/o-porcie/parametry-portu [access: 31.10.2014].

[22] LINK 2: Website of the Port of Gdansk Authority SA: http://www.portgdansk.pl/zmpg-sa/nieruchomosci [access: 28.10.2014].

[23] LINK 3: Website of the Port of Gdansk Authority SA: http://www.portgdansk.pl/zmpg-sa/przetarg-1hu2014 [access: 28.10.2014].

[24] LINK 4: Website of the Port of Gdansk Authority SA: http://www.portgdansk.pl/zmpg-sa/media?open_cat=2 [access: 29.05.2015].

[25] LINK 5: Website of the Port of Gdansk Authority SA: http://www.portgdansk.pl/o-porcie/port-w-obiektywie?photoall=1 [access: 29.05.2015].

\section{Zarządzanie zasobem portów morskich $\mathrm{w}$ relacji port - miasto portowe}

Streszczenie: Kwestia zarządzania portowym zasobem nieruchomości jest wielowymiarowa. Należy wziąć pod uwagę nie tylko lokalizację i czynniki ekonomiczne, ale również estetyczne. Zarządzanie nieruchomościami portowymi jest ściśle związane $\mathrm{z}$ zachowaniem ładu przestrzennego $\mathrm{w}$ porcie oraz $\mathrm{w}$ mieście portowym. Organ zarządzający mieniem portu realizuje kluczowe zadania w tym zakresie. W pracy przeanalizowano system zarządzania zasobem nieruchomości w Porcie Gdańsk SA (Polska). Gospodarowanie nieruchomościami portowymi odbywa się na podstawie różnych przepisów prawa, w szczególności ustawy z dnia 20 grudnia 1996 roku o portach i przystaniach.

W artykule przedstawiono niektóre działania Portu Gdańsk SA w kontekście ustawy o portach i przystaniach w stosunku do funkcjonalności portu w Gdańsku. Wyniki analizy ukazały procedury bieżącego i perspektywicznego zarządzania zasobami oraz potrzebę stworzenia systemu zarządzania zasobem nieruchomości. Na podstawie badań fokusowych autorki wskazały kierunki zrównoważonego zarządzania zasobem nieruchomości portu. 
Innowacyjnym podejściem do tej kwestii jest wskazanie sposobu zbierania danych do zarządzania branżowym zasobem nieruchomości, który jest zasobem nieruchomości portu. Port Gdańsk jest spółką łączącą obowiązki zarządzania przestrzenią oraz wykonywania czynności związanych z transportem morskim.

Słowa

kluczowe: zarządzanie nieruchomościami, zasób nieruchomości portów, miasto portowe, Zarząd Morskiego Portu Gdańsk SA 